\title{
Varicoceles in the pediatric population: Diagnosis, treatment, and outcomes
}

\author{
Thomas de los Reyes, MD; Jennifer Locke, MD, PhD; Kourosh Afshar, MD, MHSc
}

Department of Urologic Sciences, University of British Columbia, Vancouver, BC, Canada

Cite as: Can Urol Assoc J 2017;11 (1-2Suppl1):S34-9. http://dx.doi.org/10.5489/cuai.4340

See related commentary on page $\mathrm{S} 40$.

\section{Abstract}

Varicocele is commonly encountered in adolescents. There are still many controversies regarding pathophysiology, health effects, clinical significance, and optimum treatment of this condition. This article reviews the current evidence pertaining to children and adolescents with varicocele. This group present a unique and somehow challenging situation, since they are still going through pubertal changes that may confound the effects of the disease and its treatment on the developing testes.

\section{Introduction}

Pediatric varicoceles are common, affecting up to $15 \%$ of male children and adolescents. ${ }^{1}$ There is controversy surrounding the urological management of varicoceles in the pediatric population. ${ }^{1,2}$ Historically, surgical management of pediatric varicoceles was offered in higher grades or those associated with a discrepancy in testicular volume (size is $>2 \mathrm{~mL}$ or $>20 \%$ difference on the non-affected side) in order to prevent testicular function decline and infertility. 3,4 More recently, the use of surgical repair of varicoceles has been questioned with regard to whether or not it truly leads to improved clinical outcomes. Additionally, advances in surgical and radiological procedures, such as laparoscopic, microsurgical, and sclerotherapy techniques, have altered the landscape of management options for this condition.

\section{Etiology and pathophysiology}

A varicocele is the result of an abnormal enlargement of the pampiniform venous plexus, the structure responsible for venous drainage of testicles to the gonadal vein trunci, pudendal and cremasteric veins. Varicoceles are predominantly seen on the left side. Experts believe that anatomical differences in venous drainage of the testicles could be a reason for this discrepancy. ${ }^{5}$ The left testicular vein enters the renal vein while the right testicular vein enters the inferior vena cava. It was initially postulated there is a difference in hydrostatic pressure between the left and right side accounting for the differences in varicocele formation. ${ }^{6}$ In particular, the differences in length of the left and right veins and the potential compression of the left testicular vein by the superior mesenteric artery and aorta in what is known as the "nutcracker effect" may lead to increased venous pressure on the left side. ${ }^{7}$ Varicoceles are significantly more common in adolescents than in children; it is also postulated that the increased arterial blood flow to the testes at puberty exceeds the venous capacity, resulting in pampiniform venous plexus dilatation. ${ }^{8,9}$

Spermatogenesis is the testicular function most affected by the presence of a varicocele. ${ }^{10}$ In adolescents with varicoceles, decreased sperm density, increased number of pathological forms, and decreased mobility have been observed, thus, suggesting varicocele-associated reduced fertility. ${ }^{11}$ There are several postulated mechanisms by which a varicocele alters testicular function and fertility. These are outlined in Table 1. In brief, a combination of hyperthermia, hypoxia, renal and adrenal venous reflux, and increased hydrostatic pressure from the varicocele leads to increased free radicals and endocrine imbalance, and induces autoimmunity mediators that are disruptive to normal testicular function and fertility. ${ }^{12}$

\section{Epidemiology}

Varicoceles are uncommon in boys under 10 years of age. ${ }^{1}$ In adolescence, the prevalence of varicoceles typically ranges from of $10-15 \% .^{1}$ In a retrospective review by Raman et al, increased varicocele prevalence was observed in first-degree relatives (particularly brothers) of patients with known varicoceles. ${ }^{13} \mathrm{Up}$ to $40 \%$ of adult men with primary infertility have a varicocele and prevalence rises to $81 \%$ in men with secondary infertility. ${ }^{14}$ 


\section{Diagnosis and evaluation}

\section{Varicocele grading}

A varicocele can be detected clinically on physical examination with the patient in a standing position. The clinical grading system proposed by Dubin and Amelar is commonly used and consists of the following: ${ }^{15}$

- Grade I: Only palpable on Valsalva maneuver.

- Grade II: Palpable with no Valsalva maneuver.

- Grade III: Visible with no need for palpation.

With widespread availability and use of ultrasound, the World Health Organization (WHO) has expanded the current grading system to include "subclinical" or Grade 0 (not palpable including during Valsalva) varicocele, which is only detectable by ultrasonography.

The relationship between varicocele grade and ipsilateral testicular hypotrophy is not clear. In a case series published by Kass et al involving 434 boys (age range 6-21 years) with palpable varicoceles, patients with Grade II and III varicoceles had a significantly smaller ipsilateral testicle compared to controls. ${ }^{16}$ However, other studies have not shown the same correlation. ${ }^{17}$ Thus, varicocele grade alone should not be used as an indication for surgical repair.

There is currently a paucity of available data on the effects of subclinical varicoceles on testicular size or longterm fertility. In a study by Cervellione et al involving 36 children (mean age 12.8 years) with subclinical varicoceles, 10 children $(28 \%)$ had progressed to a clinically detectable varicocele at four-year followup while 24 (67\%) remained unchanged. ${ }^{18}$ Regular follow may be considered in these patients.

\section{Testicular asymmetry}

Testicular asymmetry has generally been accepted as a potential indicator for long-term subfertility and, thus, an indication for treatment of adolescent varicoceles. Testicular size and volume can be estimated in the office with an orchidometer. Some studies have shown accurate correlation between testicular volume measurements from a Prader orchidometer and ultrasonography. ${ }^{19,20}$ Others, however, support the use of ultrasonography as a more accurate modality to measure testicular volume and follow changes longitudinally. ${ }^{21,22}$ Testicular volume is often calculated using the Lambert formula (volume $=0.71 \times$ length $x$ width $x$ height). ${ }^{21}$ The accuracy of both the orchidometer and ultrasonography can be influenced by clinician experience and inter-examiner variability. Thus, a decision for surgery should be from several measurements in a consistent manner taken over a period of time.

\section{Table 1. Pathophysiology of varicocele}

\begin{tabular}{|c|c|}
\hline $\begin{array}{l}\text { Proposed } \\
\text { mechanism }\end{array}$ & Details \\
\hline Hyperthermia & $\begin{array}{l}\text { The scrotal position of the testicle allows for } \\
\text { heat exchange between the pampiniform } \\
\text { venous plexus and testicular artery regulating } \\
\text { optimal temperature for spermatogenesis. }{ }^{37} \\
\text { In humans, the presence of a varicocele leads } \\
\text { to elevated temperature of the testicle and } \\
\text { impaired spermatogenesis. } .^{38,39}\end{array}$ \\
\hline Hypoxia & $\begin{array}{l}\text { In rats, the expression of hypoxia inducible } \\
\text { factor is elevated in the presence of a varicocele } \\
\text { and subsequently decreases with repair. }{ }^{40,41} \mathrm{It} \\
\text { is postulated that stasis of blood could affect } \\
\text { partial oxygen pressure and metabolism in the } \\
\text { testis. }{ }^{42}\end{array}$ \\
\hline $\begin{array}{l}\text { Renal and } \\
\text { adrenal reflux }\end{array}$ & $\begin{array}{l}\text { In rats, it has been demonstrated that adrenal } \\
\text { and renal metabolites are refluxed down the } \\
\text { testicular vein and contribute to testicular } \\
\text { damage. }{ }^{43} \text { Reflux of blood down the testicular } \\
\text { vein has been demonstrated in patients with } \\
\text { varicoceles. }{ }^{44,45}\end{array}$ \\
\hline $\begin{array}{l}\text { Abnormal } \\
\text { blood flow }\end{array}$ & $\begin{array}{l}\text { It is postulated that increased blood flow to } \\
\text { the testicle may lead to increased hydrostatic } \\
\text { pressure and change in the composition of } \\
\text { the interstitial fluid. }{ }^{46,47} \text { This, in turn, can alter } \\
\text { the paracrine communication between Leydig } \\
\text { cells, myoid cells and Sertoli cells, altering } \\
\text { spermatogenesis. }^{48}\end{array}$ \\
\hline Free radicals & $\begin{array}{l}\text { It has been shown that increased concentration } \\
\text { of free radicals, generated by conditions } \\
\text { of hypoxia, hyperthermia, and endocrine } \\
\text { imbalance in testes associated with varicoceles, } \\
\text { leads to germ cell harm and testicular function } \\
\text { impairment in humans. }{ }^{49}\end{array}$ \\
\hline Autoimmunity & $\begin{array}{l}\text { The presence of a varicocele can disrupt } \\
\text { the blood-testis barrier and lead to } \\
\text { increased antisperm antibody and altered } \\
\text { spermatogenesis. This has been demonstrated } \\
\text { in rats, but not humans. }{ }^{12,50}\end{array}$ \\
\hline $\begin{array}{l}\text { Endocrine } \\
\text { imbalance }\end{array}$ & $\begin{array}{l}\text { The hypothalamic-pituitary-testicular axis } \\
\text { is central to testicular development and } \\
\text { function. It is postulated that altered endocrine } \\
\text { hormones as the result of the varicocele } \\
\text { can lead to decreased testicular function. } \\
\text { Increased luteinizing hormone (LH) results } \\
\text { in Leydig cell hyperplasia, which is a known } \\
\text { histological finding on varicocele testicular } \\
\text { biopsy in humans. }{ }^{51,52} \text { Furthermore, Sertoli cell } \\
\text { responsiveness to follicular stimulating hormone } \\
\text { (FSH) is decreased in patients with varicoceles } \\
\text { compared to those without varicoceles. Lastly, in } \\
\text { adults, varicoceles have been shown to reduce } \\
\text { testosterone. }{ }^{53} \text { Alterations in the hypothalamic- } \\
\text { pituitary-testicular axis by the presence of a } \\
\text { varicocele likely alter testicular function and } \\
\text { fertility. }\end{array}$ \\
\hline
\end{tabular}


de los Reyes et al.

Abnormal semen parameters have been correlated with testicular volume differentials as low as $10 \% .{ }^{23}$ Currently, threshold values for clinically significant asymmetry range from $10-20 \%$ relative difference in volume or an absolute differential of $2-3 \mathrm{~mL} .{ }^{23,24}$ On the other hand, Kolon et al observed that the degree of testicular asymmetry was reduced in up to $80 \%$ of adolescents with varicoceles due to catch-up growth of the smaller testicle without any intervention. ${ }^{25}$ Thus, the challenge lies in selecting patients with testicular asymmetry who are unlikely to have spontaneous catch-up growth of the affected testicle.

\section{Sonographic parameters}

Measurement of the peak retrograde venous flow (PRF) in the spermatic cord using Doppler colour flow imaging has emerged as a predictor for progressive testicular asymmetry. ${ }^{26} \mathrm{PRF}$ is measured with the patient performing the Valsalva maneuver in the supine position. ${ }^{26} \mathrm{~A}$ retrospective review by Kozakowski et al assessing the PRF in 77 patients (age range 9-20 years) showed that catch-up growth is rare in patients with greater than $20 \%$ asymmetry and a PRF of greater than $38 \mathrm{~cm} /$ second (mean followup 13 months). ${ }^{27}$ Poon et al had similar findings in a retrospective review involving 181 patients. ${ }^{28}$ In patients with a PRF between $30 \mathrm{~cm} / \mathrm{second}$ and $38 \mathrm{~cm} / \mathrm{second}$, data from various series show increased risk for developing progressive testicular asymmetry even when initial testicular asymmetry was less than $15 \% .{ }^{27,29,30}$

Measurement of the maximum vein diameter (MVD) of the pampiniform plexus during Valsalva in adults is a prognosticator for semen parameters following varicocele repair, with an MVD greater than $3 \mathrm{~mm}$ preoperatively associated with favourable outcomes. ${ }^{31}$ However, there is a paucity of evidence with regards to the diagnostic value of MVD in adolescents. MVD does not appear to be a reliable predictor of progression of testicular asymmetry. ${ }^{27}$

\section{Semen analysis}

In a study involving 57 Tanner stage $\mathrm{V}$ adolescent males with varicoceles and testicular asymmetry (age range 14-20 years), Diamond et al performed semen analysis that showed decreased sperm concentration and total motile sperm count. ${ }^{23}$ In a study by Moursy et al, 59 of 60 patients with a varicocele and less than $20 \%$ asymmetry managed conservatively were found to have normal semen analysis at age 18 (mean followup 79 months). ${ }^{32}$ Others have also described normalization of total motile sperm count in two-thirds of Tanner $\mathrm{V}$ boys with uncorrected varicocele. ${ }^{33}$ On the other hand, randomized trials have shown improvement in semen parameters following varicocelectomy (see Treatment and outcomes). There are no standard norms for adolescent semen analysis. Currently, the WHO adult standards are extrapolated to this group. In evaluating the data available thus far, the current role of semen analysis in the evaluation of adolescent varicocele remains unclear.

\section{Endocrine evaluation}

The presence of varicocele has been postulated to affect testosterone production and, in turn, the hypothalamicpituitary-gonadal axis. Multiple studies involving adult men have shown an improvement in testosterone levels postvaricocele repair. ${ }^{34}$ Although testosterone measurements are affected by multiple factors, such as the assay technique itself, lifestyle factors and age, most recent evidence in adults suggest a positive relationship between varicocele repair and improvement in testosterone levels. ${ }^{34,35}$ In a recent crosssectional study by Daamsgard et al involving 7035 men (median age 19 years), 1102 (15.7\%) men had a palpable varicocele. ${ }^{36}$ The presence of a varicocele was associated with higher baseline serum follicle-stimulating hormone $(\mathrm{FSH})$ and luteinizing hormone ( $\mathrm{LH})$ levels, and lower serum inhibin B levels, with a trend towards greater deviation from controls as varicocele grade increased. ${ }^{36}$ There was no difference in baseline serum testosterone levels in those with varicoceles compared to those without. ${ }^{36}$

There are, however, practical considerations to bear in mind with regards to endocrine evaluation in adolescents. This includes defining standard norms for adolescents with varying tanner stages and the cost of testing and multiple blood draws, especially if done pre- and post-procedure. Taken together, the utility of obtaining baseline hormonal evaluation in identifying adolescents at risk for infertility has not yet been demonstrated and the significance of testosterone change pre- and post-intervention remains unclear.

\section{Treatment and outcomes}

\section{Indications for treatment}

The diagnostic evaluation of adolescents with varicoceles continues to evolve. Patients should be followed regularly with serial physical examination and assessment of testicular size as the bare minimum.

There continues to be a lack of consensus on the threshold for testicular asymmetry $(10 \%, 15 \%$, or $20 \%)$ that warrants varicocele intervention. The decision for surgery should be from several measurements taken over a period of time and in a consistent manner. The effect of ongoing pubertal changes and the possibility of spontaneous catch-up growth should be taken into account. 


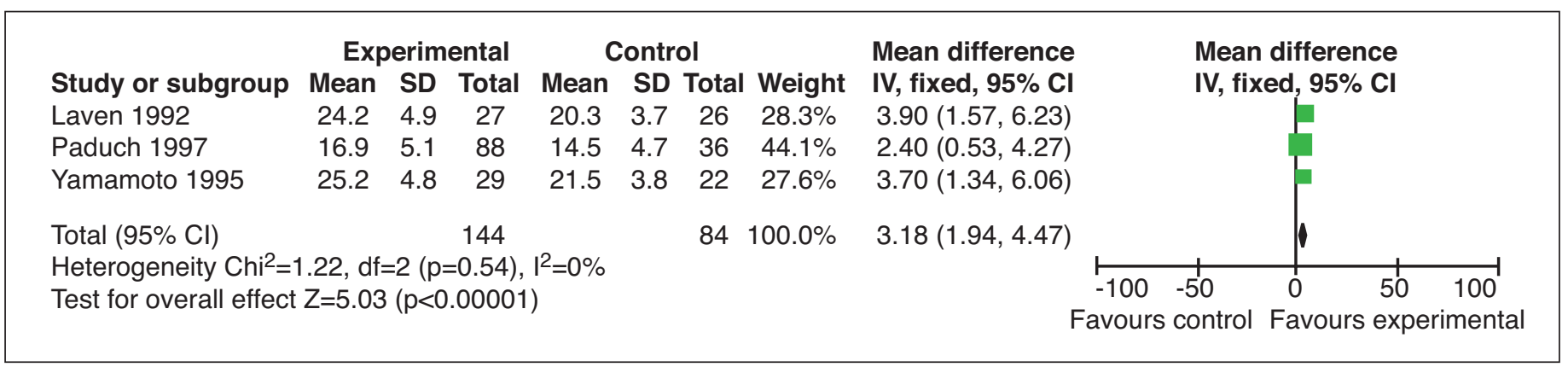

Fig. 1. Forest plot of comparison between surgical or radiological intervention to conservative management, outcome: Changes in testicular volume. Cl: confidence interval; SD: standard deviation.

Ultrasonography is an accurate modality for following testicular size, as it enables clinicians to compare previous images and measurements more precisely. In patients with testicular asymmetry, measurement of the PRF may be helpful in selecting which patients are likely to demonstrate catch-up growth vs. those who may benefit from early intervention. Based on the data available, surgical intervention should be considered in patients with a PRF of greater than $38 \mathrm{~cm} /$ second and concurrent testicular asymmetry greater than $20 \%$.

In Tanner $\mathrm{V}$ adolescents, semen analysis can be considered as an additional way to assess testicular function. The semen analysis may help the patient and clinician in reaching a decision as to whether an intervention should be performed.

A plethora of different types of interventions to treat varicocele exist in the literature. These range from monitoring to open surgery. The procedural interventions may be divided into open, laparoscopic, and endovascular procedures. All the procedures involve occlusion of the testicular veins or pampiniform plexus. The anatomical site of occlusion varies from distal spermatic cord (low inguinal) to proximal testicular vein (retroperitoneal). Multiple variations in techniques have been reported, primarily to reduce postoperative failures and complications.
Examples are arterial- and lymphatic-sparing approaches to reduce the risk of testicular atrophy and hydrocele, respectively.

Our group recently conducted a systematic review of randomized, controlled trials to assess the outcomes of radiological and surgical interventions for varicocele in children and adolescents. We did not include cases series and uncontrolled studies since they tend to overestimate the effect of intervention. In our meta-analysis of nine eligible studies at six months' followup, we demonstrated an improvement in testicular volume (mean difference $3.18 \mathrm{~mL}$ [95\% confidence interval (CI) 1.94-4.42]) and in sperm count (mean difference $25.54 \times 10^{6} / \mathrm{mL}$ [95\% Cl 12.84-38.25]) in patients who underwent radiological or surgical treatment as compared to conservative management (Figs. 1 and 2 , respectively). Morphology and motility parameters were not changed significantly following intervention. Paternity rates following adolescent varicocele repair have not been evaluated in randomized, controlled trials. Nevertheless, Bogaert et al were not able to show any significant difference in paternity in an observational study that followed the participants for over 15 years. ${ }^{54}$

Lastly, there was no statistically significant difference in other variables, including operating time and length of stay, observed. Varicocele recurrence and hydrocele have

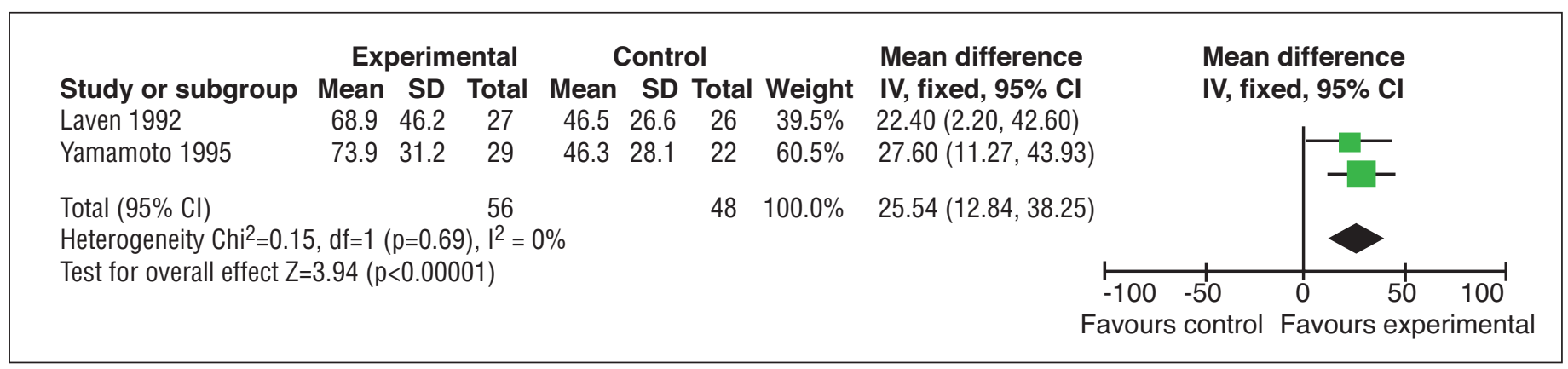

Fig. 2. Forest plot of comparison between surgical or radiological intervention to conservative management, outcome: Sperm concentration. Cl: confidence interval; SD: standard deviation. 
de los Reyes et al.

been reported with a prevalence of $0-31 \%$ and $0-13 \%$, respectively. The quality of the studies is moderate to low.

In conclusion, currently there is a moderate level of evidence that treatment of varicocele in adolescents may improve testicular growth and sperm density.

Competing interests: The authors report no competing personal or financial interests.

This paper has been peer-reviewed.

\section{References}

1. Akbay E, Cayan S, Doruk E, et al. The prevalence of varicocele and varicocele-related testicular atrophy in Turkish children and adolescents. BJU Int 2000;86:490-493. https://doi.org/10.1046/j.1464410X.2000.00735.x

2. Meacham RB, Townsend RR, Rademacher $D$, et al. The incidence of varicoceles in the general population when evaluated by physical examination, gray scale sonography, and colour Doppler sonography. J Urol 1994;151:1535-8

3. Pintus C, Rodriguez Matas MJ, Manzoni C, et al. Varicocele in pediatric patients: Comparative assessment of different therapeutic approaches. Urology 2001;57:154-7. https://doi.org/10.1016/S00904295(00)00859-1

4. Baazeem A, Belzile E, Ciampi A, et al. Varicocele and male factor infertility treatment: A new meta-analysis and review of the role of varicocele repair. Eur Urol 2011;60:796-808. https://doi.org/10.1016/i. eururo.2011.06.018

5. Waalkes R, Manea IF, Nijman JM. Varicocele in adolescents: A review and guideline for the daily practice. Archivos Espanoles de Urologia 2012;65:859-871.

6. Paduch DA, Skoog SJ. Diagnosis, evaluation and treatment of adolescent varicocele. ScientificWorldJournal 2004;4 Suppl 1:263-78. https://doi.org/10.1100/tsw.2004.76

7. Stassen CM, Weil EH, Janevski BK. Left renal vein compression syndrome ("nutcracker phenomenon") RoFo 1989;150:708-10. https://doi.org/10.1055/s-2008-1047107

8. Green KF, Turner TT, Howards SS. Varicocele: Reversal of the testicular blood flow and temperature effects by varicocele repair. J Urol 1984;131:1208-11.

9. Nagler HM, Lizza EF, House SD, et al. Testicular hemodynamic changes after the surgical creation of a varicocele in the rat. Intravital microscopic observations. J Androl 1987:8:292-8. https://doi.org/10.1002/j.1939-4640.1987.tb00964.x

10. Micic $S$, Illic V, Isvaneski M. Correlation of hormone and histologic parameters in infertile men with varicocele. Urologia Internationalis 1983;38:187-90. https://doi.org/10.1159/000280888

11. Paduch DA, Niedzielski J. Semen analysis in young men with varicocele: Preliminary study. J Urol 1996;156:788-90. https://doi.org/10.1016/S0022-5347(01)65816-6

12. Naughton CK, Nangia AK, Agarwal A. Pathophysiology of varicoceles in male infertility. Hum Reprod Update 2001;7:473-81. https://doi.org/10.1093/humupd/7.5.473

13. Raman JD, Walmsley K, Goldstein M. Inheritance of varicoceles. Urology 2005;65:1186-9 https://doi.org/10.1016/i.urology.2004.12.057

14. Gorelick JI, Goldstein M. Loss of fertility in men with varicocele. Fertil Steril 1993;59:613-6. https://doi.org/10.1016/S0015-0282(16)55809-9

15. Dubin L, Amelar RD. Varicocele size and results of varicocelectomy in selected subfertile men with varicocele. Fertil Steril 1970;21:606-9. https://doi.org/10.1016/S0015-0282(16)37684-1

16. Kass EJ, Stork BR, Steinert BW. Varicocele in adolescence induces left and right testicular volume loss. BJU Int 2001;87:499-501.https://doi.org/10.1046/i.1464-410X.2001.00144.X

17. Alukal JP, Zurakowski D, Atala A, et al. Testicular hypotrophy does not correlate with grade of adolescent varicocele. J Urol 2005;174:2367-70. htrps://doi.org/10.1097/01.ju.0000180418.23208.1d

18. Cervellione RM, Corroppolo M, Bianchi A. Subclinical varicocele in the pediatric age group. J Urol 2008;179:717-9. https://doi.org/10.1016/i.juro.2007.09.095

19. Goede J, Hack WW, Siistermans K, et al. Normative values for testicular volume measured by ultrasonography in a normal population from infancy to adolescence. Horm Res Paediatr 2011;76:56-64. https://doi.org/10.1159/000326057

20. Schiff JD, Li PS, Goldstein M. Correlation of ultrasonographic and orchidometer measurements of testis volume in adults. BJU Int 2004;93:1015-7. https://doi.org/10.1111/i.1464-410X.2003.04772.x
21. Sakamoto H, Saito K, Oohta $M$, et al. Testicular volume measurement: Comparison of ultrasonography, orchidometry, and water displacement. Urology 2007;69:152-7. https://doi.org/10.1016/i. urology.2006.09.012

22. Diamond DA, Paltiel HJ, DiCanzio J, et al. Comparative assessment of pediatric testicular volume: Orchidometer vs. ultrasound. J Urol 2000;164:1111-4. https://doi.org/10.1016/S00225347(05)67264-3

23. Diamond DA, Zurakowski D, Bauer SB, et al. Relationship of varicocele grade and testicular hypotrophy to semen parameters in adolescents. J Urol 2007;178:1584-8. https://doi.org/10.1016/i. juro.2007.03.169

24. Skoog SJ, Roberts KP, Goldstein M, et al. The adolescent varicocele: What's new with an old problem in young patients? Pediatrics 1997;100:112-21. https://doi.org/10.1542/peds.100.1.112

25. Kolon TF, Clement MR, Cartwright L, et al. Transient asynchronous testicular growth in adolescent males with a varicocele. J Urol 2008;180:1111-4. htrps://doi.org/10.1016/i.juro.2008.05.061

26. Cimador M, Castagnetti M, Gattuccio I, et al. The hemodynamic approach to evaluating adolescent varicocele. Nat Rev Urol 2012;9:247-57. https://doi.org/10.1038/nrurol.2012.41

27. Kozakowski KA, Gjertson CK, Decastro GJ, et al. Peak retrograde flow: A novel predictor of persistent, progressive and new onset asymmetry in adolescent varicocele. J Urol 2009;181:2717-22. https://doi.org/10.1016/i.juro.2009.02.038

28. Poon SA, Gjertson CK, Mercado MA, et al. Testicular asymmetry and adolescent varicoceles managed expectantly. J Urol 2010;183:731-4. https://doi.org/10.1016/i.juro.2009.10.028

29. Korets R, Woldu SL, Nees SN, et al. Testicular symmetry and adolescent varicocele - does it need followup? J Urol 2011;186:1614-8. htrps://doi.org/10.1016/i.juro.2011.03.068

30. Van Batavia JP, Badalato G, Fast A, et al. Adolescent varicocele - is the $20 / 38$ harbinger a durable predictor of testicular asymmetry? J Urol 2013;189:1897-1901. https://doi.org/10.1016/i. juro.2012.11.011

31. Schiff JD, Li PS, Goldstein M. Correlation of ultrasound-measured venous size and reversal of flow with Valsalva with improvement in semen-analysis parameters after varicocelectomy. Fertil Steril 2006;86:2502. https://doi.org/10.1016/iffertnstert.2005.12.038

32. Moursy EE, ElDahshoury MZ, Hussein MM, et al. Dilemma of adolescent varicocele: Long-term outcome in patients managed surgically and in patients managed expectantly. J Ped Urol 2013;9:1018-22. https://doi.org/10.1016/i.jpurol.2013.01.017

33. Kolon TF. Evaluation and management of the adolescent varicocele. J Urol 2015;194:1194-201. https://doi.org/10.1016/i.juro.2015.06.079

34. Fisch H, Hyun G. Varicocele repair for low testosterone. Curr Opin Urol 2012;22:495-8. https://doi.org/10.1097/MOU.0b013e328358e0fb

35. Trost LW, Mulhall JP. Challenges in testosterone measurement, data interpretation, and methodological appraisal of interventional trials. J Sex Med 2016;13:1029-46. https://doi.org/10.1016/i.jsxm.2016.04.068

36. Damsgaard J, Joensen UN, Carlsen E, et al. Varicocele is associated with impaired semen quality and reproductive hormone levels: A study of 7035 healthy young men from six European countries. Eur Urol 2016. [Epub ahead of print]. htrps://doi.org/10.1016/i.eururo.2016.06.044

37. Zorgniotti AW. Testis temperature, infertility, and the varicocele paradox. Urology 1980;16:7-10. https://doi.org/10.1016/0090-4295(80)90321-0

38. Hienz HA, Voggenthaler J, Weissbach L. Histological findings in testes with varicocele during childhood and their therapeutic consequences. Eur J Ped 1980;133:139-46. https://doi.org/10.1007/BF00441582

39. Garolla A, Torino M, Miola P, et al. Twenty-four-hour monitoring of scrotal temperature in obese men and men with a varicocele as a mirror of spermatogenic function. Hum Reprod 2015;30:1006-13. https://doi.org/10.1093/humrep/dev057

40. Paick JS, Park K, Kim SW, et al. Increased expression of hypoxia-inducible factor-lalpha and connective tissue growth factor accompanied by fibrosis in the rat testis of varicocele. Actas Urologicas Espanolas 2012;36:282-8. htrps://doi.org/10.1016/i.acuro.2011.07.022

41. Goren MR, Kilinc F, Kayaselcuk F, et al. Effects of experimental left varicocele repair on hypoxia-inducible factor-lalpha and vascular endothelial growth factor expressions and angiogenesis in rat testis. Andrologia 2016 [Epub ahead pf print]. https://doi.org/10.1111/and.12614

42. Netto NR Jr, Lemos GC, De Goes GM. Varicocele: Relation between anoxia and hypospermatogenesis. Int J Fertil 1977:22:174-8.

43. Camoglio FS, Zampieri N, Corroppolo $M$, et al. Varicocele and retrograde adrenal metabolites flow. An experimental study on rats. Urologia internationalis 2004;73:337-42. https://doi.org/10.1159/000081595

44. Mali WP, Oei HY, Arndt JW, et al. Hemodynamics of the varicocele. Part II. Correlation among the results of renocaval pressure measurements, varicocele scintigraphy, and phlebography. J Urol 1986;135:489-93.

45. Mali WP, Arndt JW, Coolsaet BL, et al. Hemodynamic aspects of left-sided varicocele and its association with so-called right-sided varicocele. Int J Androl 1984;7:297-308. https://doi.org/10.1111/j.1365-2605.1984.tb00787.x 
46. Sweeney TE, Rozum JS, Gore RW. Alteration of testicular microvascular pressures during venous pressure elevation. Am J Physiol 1995;269:H37-45.

47. Gat Y, Zukerman Z, Chakraborty J, et al. Varicocele, hypoxia, and male infertility. Fluid mechanics analysis of the impaired testicular venous drainage system. Hum Reprod 2005;20:2614-9. https://doi.org/10.1093/humrep/dei089

48. Santamaria L, Martin R, Nistal $M$, et al. The peritubular myoid cells in the testes from men with varicocele: An ultrastructural, immunohistochemical, and quantitative study. Histopathology 1992;21:423-33. https://doi.org/10.1111/i.1365-2559.1992.tb00426.x

49. Romeo C, Santoro G. Free radicals in adolescent varicocele testis. Oxid Med Cell Longev 2014;2014:912878. https://doi.org/10.1155/2014/912878

50. Jarow JP, Sanzone JJ. Risk factors for male partner antisperm antibodies. J Urol 1992;148:1805-7.
51. McFadden MR, Mehan DJ. Testicular biopsies in 101 cases of varicocele. J Urol 1978;119:372-4.

52. Hadziselimovic $F$, Leibundgut $B$, Da Rugna $D$, et al. The value of testicular biopsy in patients with varicocele. J Urol 1986;135:707-10

53. Alkaram A, McCullough A. Varicocele and its effect on testosterone: Implications for the adolescent. Transl Androl Urol 2014;3:413-7.

54. Bogaert $G$, Orye $C$, De Win $G$. Pubertal screening and treatment for varicocele do not improve chance of paternity as adult. J Urol 2013;189:2298-303. https://doi.org/10.1016/i.juro.2012.12.030

Correspondence: Dr. Kourosh Afshar, Department of Urologic Sciences, University of British Columbia, Vancouver, BC, Canada; kafshar@cw.bc.ca 